\title{
The Genesis of the Idea and Value of Political Peace in Early Modern Political Philosophy
}

\author{
RAUL RAUNIĆ \\ Faculty of Humanities and Social Sciences, University of Zagreb
}

\begin{abstract}
Summary
The main intention of this paper is to reconstruct the conceptual and historical genesis of the idea and value of political peace from the point of view of political philosophy at the intersection between late scholasticism and early modernity. The paper consists of three related parts. The first part highlights methodological and contextual reasons why the idea of political peace has been overshadowed throughout history by dominant discourses on war. The second part deals with conceptual clarifications. The nature of war is distinguished from other types of conflict and three interpretative approaches to war are analyzed: political realism, fundamentalist-moralistic view of the holy war, and the many theories of natural law that give rise to conceptions of just war, but also the first abolitionist perspective or idea of ending all wars. Early theoretical articulations of the notion of peace indicated modern-day emancipation of politics from the tutelage of metaphysics and classical ethics, thus separating the value of political peace from its original oneness with cosmic and psychological peace. The third part of the paper highlights key moments in the historical genesis of the value of political peace in the works of Aurelius Augustine, Marsilius of Padua, and William of Ockham.

Keywords: Violence and War, Political Peace, Aurelius Augustine, Marsilius of Padua, William of Ockham
\end{abstract}

\section{Introduction}

The primary intention of this paper is to reconstruct the preconditions and genesis of the idea and value of political peace that led to the theoretical articulation of the two most influential conceptions of political peace in the early modern period. The first one is Hobbes's conception of political peace which is based on the principles of instrumental rationality and mutual advantages in the pragmatic concept of modus vivendi, whereas the second one is Kant's ethical-legal conception which for 
the first time elevates humanity to the status of an ethical and legal subject in the cosmopolitan project of eternal peace. Both Hobbes's and Kant's conceptions are certainly worthy of special and separate consideration. However, in this paper, I will analyze the reasons and causes that made the idea of political peace an important theme and value of philosophical and theoretical-political considerations at the threshold between the Middle Ages and the modern era.

Theoretical interest in the idea and value of political peace stems from a multitude of reasons. The underlying theoretical reason lies in the fact modern political philosophy and ethics challenge the instrumentalization of human lives in the name of so-called higher religious, ideological and metaphysical goals, thus gradually affirming the naturalistic principle of factuality and human life as a value and moral right in itself. From today's perspective, there are two additional motives for interest in the subject of peace. The centennial anniversary of the First World War, the first world conflict of global proportions, provides historical distance for a muchneeded reflection on humankind's self-inflicted tragedies. Moreover, one of Hobbes's illustrations of the factual equivalent of his methodical construction of 'natural state' - an international community in which ' ... in all times, Kings, and Persons of Sovereign Authority, because of their Independency, are in continual jealousies, and in the state and posture of Gladiators, having their weapons pointing, and their eyes fixed on one another" - is still relevant today, just like his famous definition according to which war "consisteth not in Battell only, or the act of fighting; but in a tract of time, wherein the Will to contend by Battell is sufficiently known..."

The primary intention of the paper will be explained through three related sections. First, I will point out the methodological and contextual reasons why the idea of political peace has always been overshadowed throughout its history by dominant discourses on war. At the same time, I will outline the preconditions and reasons why the value of political peace was positively established in the modern era nonetheless.

In the second part of the paper, I will emphasize the need for conceptual delineations and clarifications with regard to discourses on both war and peace. Furthermore, I will examine elementary distinctions - that is, definitions of war on the one hand, and various types of conflict on the other - as well as differences between three interpretative approaches to war: political realism, fundamentalist-moralistic view of holy war, and various theories of natural law and their derivatives. Within this last position, I will single out the distinction between justified and unjustified wars, as well as the abolitionist perspective aiming at effectively ending all wars.

${ }^{1}$ Hobbes, 1985, part I, chap. XIII, pp. 185-187. In short, war is potentially present anytime and anywhere where there are no guarantees of peace. 
When it comes to the discourse on peace, it is analytically important to distinguish three fundamental uses of the term 'peace' in the European history of ideas: a) cosmic or metaphysical peace; b) peace of a city/state or political peace; c) inner, mental or psychological peace. With the modern emancipation of politics from the tutelage of metaphysics and classical ethics, and with the dissolution of the original unity of these three levels of peace, the value of political peace has become a specific issue of political philosophy and political theory.

In the third part of the paper, I will highlight key moments in the historical genesis of the public moral idea and value of political peace in the works of Aurelius Augustine, Marsilius of Padua, and William of Ockham.

In conclusion, I would like to point out two main points. The historical genesis and conceptual analysis of the value of political peace show that it does not belong to metaphysical or worldview morality, but rather that it belongs to public or political morality important for liberal-democratic political culture. And secondly, political peace is not the opposite of rivalry and conflict in utopian reveries beyond all social and political tensions, political peace is the opposite of war or violent and unscrupulous conflict resolution.

\section{Discourses on War vs. Discourses on Peace}

How to understand the relationship between war and peace? Should this relationship be viewed solely, or at least primarily, at an intuitively persuasive linear and synchronic level that reveals their diametrically opposed natures? Or should one also permit - and under what conditions - diachronic considerations that regard the relationship between war and peace within the framework of relative functional connection, revealing at the same time the paradoxical nature of war? Every (or almost every) war ideologically seeks to legitimize itself as a pursuit of peace - that is, violence is allegedly resorted to solely for the purpose of eliminating violence. ${ }^{2}$

2 The first relatively systematic philosophical discussion of peace as an ethical and political ideal - in fact, an ontologically determined aspiration of every single nature, particularly human nature - is brought up by Aurelius Augustine in chapter XIX of his famous work The City of God. From the ontological and moral-psychological premise of the universal human striving for peace, Augustine exposes the paradoxical nature of war. "[If] there is no man who does not wish to be joyful, neither is there anyone who does not wish to have peace. For even they who make war desire nothing but victory - desire, that is to say, to attain to peace with glory. For what else is victory than the conquest of those who resist us? And when this is done there is peace. It is therefore with the desire for peace that wars are waged..." (Augustin, 1996, XIX, 12.1, p. 45). Admittedly, Aristotle also mentioned that "the goal of war is peace" (Politics, 1988a, 1334 a 15, p. 246), but only incidentally as a conceptual pair with 'occupation' and 'leisure', illustrating the complexity of statesmanship. 
Discourses on war have throughout history quantitatively considerably overshadowed discourses on peace. High moral justifications for war have always been sought and always found - violated dignity, pride, justice, faith, sacredness, defense of life. Peace, on the other hand, has usually been defined in a descriptive and methodically negative way - as a state in which there is no war; or pragmatically - as a state ensuing when warring parties, due to their exhaustion, have practically no other option but peace, or when one side completely defeats the other, leading to unconditional surrender and the so-called victorious peace. ${ }^{3}$ There are several reasons why discourses on war have gained normative priority. ${ }^{4}$ First and foremost, the main reason at the phenomenological level is the human fascination with violence. The usual legalistic definitions of violence as the unlawful use of force in causing injuries and damage are obviously too narrow. Not only do they not explain war conflicts between states, but they also overlook the existence of situations where it is illegal, although obviously legitimate to resort to violence. On the other hand, too broad uses of the concept of violence, which include fundamental social injustices or the so-called structural violence, as well as linguistic forms as an aspect of symbolic violence, show the diversity and diffused limits of the phenomenon of violence, but at the same time analytically blur the essence of violence more than they illuminate it. ${ }^{5}$ Therefore, we are left with an intuitively acceptable definition

${ }^{3}$ Reliable philosophical studies about peace are very rare in Croatian philosophical literature. One exception are the highly instructive studies by Žarko Puhovski, which this paper relies on as well. See Puhovski (2003, 2015, 2018).

${ }^{4}$ Among the first to effectively expose the paradoxical nature of the human relationship to war and peace was Erasmus of Rotterdam. In his essay "The Complaint of Peace", the personification of peace never ceases to wonder at the fact that despite being the basis of all human good, everywhere it goes seeking rest - among kings, priests, prophets, scholars - it is despised and rejected, while war, which brings destruction and misery, is at the same time extolled and eulogized. Peace is particularly dismayed to learn that from those whom, in view of Christ's message of peace, unity and mutual love, he expected the most from - Christian rulers and priests - he receives nothing but an ungodly and blasphemous championing of war. Erasmus's bitter persiflage of the foolishness of the human race - because "we may be angry with the wicked, but we can only pity the insane" (p. 2) - nonetheless ends with an appeal "to all who call themselves Christians... to unite with one heart and one soul, in the abolition of war, and the establishment of perpetual and universal peace" (p. 77). See Erasmus, 1917 (A.D. 1521). However, when it comes to his pacifist sentiments, it should be added that, in accordance with the actions of Pope Leo X, Erasmus confines the ideal of peace to res publica Christiana, with the aim of fighting the Turks more efficiently.

${ }^{5}$ An example of one such (too) broad use of the term 'violence', which conflates the phenomena of violence, structural social injustices, power and authority, but does not distinguish legitimate from illegitimate uses, force from power, or domination from authority, is Slavoj Žižek's book Violence (2008), which is based on the Foucaultian paradigm of the ubiquitous and all-pervasive microphysics of power. 
according to which violence is direct, illegal and illegitimate use of coercion in causing objectively identifiable harm to the other party despite their opposition. Violence is characterized by immediacy, speed of action and efficiency. It is the most primitive, but also the most widespread way of communication understood even by those who pretend not to understand, as well as by those who really have trouble understanding. The self-evidence and naturalness of violence allows for arbitrariness, temporary exoneration from justification - you can just because you can - and the position of ultimate judge.

In a long-term perspective, nevertheless, violence reveals its instrumental nature. This means that it tries to be understood with regard to the goals it leads to or seeks to achieve. Such justification of violence through the prism of righteous goals, however, only partially touches upon the nature of violence, since goals determine the permissibility of the use of violence (Benjamin, 1971) rather than violence as such. Moreover, not only do justified goals tell the truth about the nature of violent means, but vice versa as well - the nature of violent means, despite selfdeceptive rationalizations, also reveals the truth about the goals themselves.

It is perfectly acceptable that there are situations, such as self-defense, where resorting to violence is the most rational choice. ${ }^{6}$ However, such situations, in which ends may justify violent means, require that there should be no viable alternatives to violent means and that the ends should be coerced, existentially crucial, immediate and short-term. Any long-term, systemic and strategic use of violence transforms violence from a coerced and possibly justified reaction into an unjustified and illegitimate principle of action. ${ }^{7}$

${ }^{6}$ Pacifism, or unconditional elimination of violence, is a kind of moral absolutism and as such prima facie attractive, but nonetheless an overly demanding and hardly feasible position. This does not mean underestimating pacifism, especially its moral value, but primarily means, in the absence of institutional guarantees, a limited political reach of such a view. The classic pacifism of the Western cultural circle, in its many different forms and manifestations, was initially associated with the lifestyles of isolated religious communities - for instance, the Christian movement in the first three centuries of the new era and modern Protestant denominations such as Mennonites, Amish and Quakers - but also with various philosophical and secular traditions. Modern and contemporary pacifism, with its standard anchorage in the absolute moral duty of nonviolence and respect for life, at the political level occasionally evolves into the theory and practice of civil disobedience, nonviolent resistance and active commitment to the values of a new culture of peace. See Fiala (2018 and 2018a).

${ }^{7}$ Hannah Arendt's distinction between the conditional justification of violence and the unconditional illegitimacy of violence, regardless of its seeming contradiction, appears to be a plausible theoretical model for considering the complexity of the phenomenon of violence. Resorting to violence can be justified only by the crucial and existential importance of an immediate future goal in exceptional and coerced situations, but it cannot be legitimate in terms of a priori authorization for the strategic use of violence. See Arendt (1969). 
It is common for violence to be given a special place in collective memory and in the formation of social and political identities due to its natural self-evidence and high effectiveness, resistance to which could even endanger one's life. The warriors' customary morality seems naturally occurring, dominant and almost universally present, strictly identifying the space of one's moral affirmation with that of a battlefield. ${ }^{8}$ Wars, such narratives tell us, create heroes, while peace brings only a lack of challenge and stagnant mediocrity. Eternal enemies, crucial battles, political myths and fabrication of tradition lead to collective identifications, providing a compelling foothold for ethnic and national identities (Tudor, 1972; Hobsbawm and Ranger, 2007; Bottici, 2007; Monneyron and Mouchtouris, 2012).

Another, related, reason for the privileged status of discourse on war is that no other human activity instigates such a total mobilization of people. Systemic verbal violence and the propagation of war rhetoric, as well as various symbolic and physical incitements and provocations, abruptly narrow down the room for decision-making and action-taking on the part of the silent, skeptical and frequently reserved majority. All moral, intellectual, cultural, worldview, social and political differences between people are drowned in the boiling water of massification and polarizing homogenization. Enormous mobilization forces lead to homogenization within groups and antagonization with regard to others. In such a suddenly reduced picture of the world there remains only the newly created total opposition: friendenemy. ${ }^{9}$ The dramatics of war rhetoric and the tragedy of war result from the fact that war morally empowers, legally encourages and even requires the mass taking of others' lives and sacrificing one's own (Puhovski, 2003). Such authorization to do anything and the elimination of every civilizational consideration are deeply and traumatically etched into the collective memory. Phenomenological experiences of war and its aftermath show that social tectonics and destruction of massive propor-

8 The assumed connection between a valid moral argument and martial domination, right reason and military victory, is also emphasized in a number of philosophical reflections, from Augustine's narrative of Joshua's appeal to God in a battle against the Amorites (Confessions, XI, 23, p. 271) to Locke's biblical illustration of Jephthah's victory over the Ammonites or "an appeal to heaven" - that is, a call to God, in the absence of a judge on earth, to judge the legitimacy of the people's armed resistance and help them achieve victory against self-willed and rebellious rulers (Two Treatises, b. II, ch. III, sec. 21, p. 282 and ch. XIV, p. 379).

9 Contrary to the consensus perspective in understanding politics, according to which, with the onset of the state of war, politics ceases and is replaced by military tactics and strategy, Carl Schmitt advocates the conflicting perspective according to which a total conflict between substantive national collectivities, expressed in a variety of ways and present in all relevant spheres of life, is not the end of politics, but its very essence. Hence Schmitt's famous formulaic reduction of politics to the political distinction between friend and enemy, where "war is just the extreme realization of enmity" (Schmitt, 2007: 74). 
tions, with huge casualties and numerous victims, also create shortcuts - both figuratively and literally over people's heads - in achieving collective, group and individual goals. The moral and political umbrella of "state of war" and the so-called higher, historical and decisive reasons, in the name of which everything is permissible, eliminate ethically motivated inhibitions, a priori exonerate from moral judgment and questioning of the moral cost of realizing collective shortcuts, such as the redistribution of natural and social resources, violent industrialization and modernization, bloc alignments, nationalist self-affirmation, imperial aspirations, geopolitical determinations. All these motives, due to their mobilizing and legitimizing effects, are wrapped up in ideological forms of seemingly inescapable, binding and right reasons, but ultimately rely on the silent effectiveness of violence. The state of war destroys the entire existing social structure and, in addition to numerous casualties, creates war profiteers and renters who during the war and in its aftermath profoundly determine the course of material and conceptual reproduction of society.

The third and perhaps most fundamental reason for the ubiquity of discourses on war is the explicit or implicit premise of the inevitability or even necessity of wars. This metaphysical way of looking at things can take two basic forms: dialectical and theodicial. Dialectical or strong conceptions, ranging from Heraclitus ${ }^{10}$ to Hegel $^{11}$, hold that the strife of opposites is inherent in everything that exists and that war, therefore, governs - both figuratively and literally - the world of human affairs as well. Theodicial or moderate conceptions, ranging from Augustine's eschatology

10 The ontological and metaphorical meaning is most directly expressed in Heraclitus's fragment 53: "War is father of all, and king of all. He renders some gods, other men; he makes some slaves, others free."

11 In his Encyclopedia of the Philosophical Sciences, Hegel repeatedly points out that dialectics is not "an adventitious art, which for very wantonness introduces confusion and a mere semblance of contradiction into definite notions", but, rather, that it is "the very nature and essence of everything predicated by mere understanding - the law of things and of the finite as a whole" (par. 81, p. 101). Reality is, therefore, "quality, as determinateness which is, as contrasted with the negation which is involved in it but distinguished from it. The negation is no longer abstract nothing, but as a being-there and as something, it is only a form of the something: it is as otherness" (par. 91, p. 110). This ontological principle of negativity at the level of international relations appears as sovereignty to the outside and, thus, the actuality of war. "The ethical moment of war is implicit in what was stated above, for war should not be regarded as an absolute evil and as a purely external contingency whose cause is therefore itself contingent, whether this cause lies in the passions of rulers or nations, in injustices etc., or in anything else which is not as it should be" (Elements of the Philosophy of Right, par. 324, p. 449). In short, with his ontological argument - "The state is an individual, and negation is an essential component of individuality; thus, even if a number of states join together as a family, this league, in its individuality, must generate opposition and create an enemy" (ibid., par. 324. Addition, p. 450) - Hegel rejects Kant's project of perpetual peace as the highest practical ideal. 
of salvation to Rousseau's ${ }^{12}$ and Marx's ${ }^{13}$ secular philosophy of history leading to, respectively, civil and universal human emancipation, hold that conflict, war and destruction are necessary but also final because they create the prerequisites for the ultimate emancipation and the triumph of good. Both of these conceptions - dialectical and theodicial - share two basic characteristics. The subject of history is divided into the primary, metaphysical level, whether it being logos, world spirit, God's predestination, providence of nature, conflict between production relations and productive forces, and the secondary realm of human action which, through people's passions and intentions, unknowingly serves metaphysical purposes. Secondly, such a world divided into higher and lower realms explicitly or implicitly abolishes human responsibility in warfare by appealing to higher, metaphysical or historical reasons in the name of which everything is permissible (Raunić, 2018). All three of these reasons - natural self-evidence, directness and effectiveness of war violence; authorization to do anything during the war and the suppression of all differences within belligerents while at the same time rejecting any consideration for others; and, finally, belief in the necessity and unavoidability of war - support the centuries-old dominance of discourse on war. It was only in the modern era that the prerequisites for the affirmation of the idea of political peace as a public-moral ideal were created, primarily due to the following key factors: ${ }^{14}$

1. The affirmation of human life and the self-positioning of man. Late-Renaissance humanism affirmed the principle of individual subjectivity and elevated the value of human life. Modern political philosophy, rudimentarily in Machiavelli's writings and systematically in Hobbes's, articulated the idea of the emancipation of humankind from the normativity of nature and God's predestination - affirming the self-positioning of human cohabitation in will and construction.

12 For Rousseau's theodicial model of history set forth in his works A Discourse upon the Origin and Foundations of Inequality Among Men and The Social Contract, see Neuhouser (2008) and Raunić (2014).

13 Marx's philosophy of history, which replaces Hegel's labor of the concept or phenomenology of consciousness with the concept of labor or the self-creation of man, finds in the inevitability of the course of history the structural condition for world revolution and the radical emancipation of man. As Marx says, "the transcendence of self-estrangement follows the same course as selfestrangement" ("Private Property and Communism", Marx, 1976: 272); that is, "communism is the riddle of history solved and it knows itself to be this solution" (ibid.: 275). This inverted and prospectively set Hegel's legacy is manifested in the temptations of teleological knowledge of the necessary course of history (see particularly Marx's afterword to the second edition of Capital), which then leads to philosophy of history displacing political philosophy or making it unnecessary (cf. Löwith, 1990).

${ }^{14}$ A broader overview of these factors can be found in Raunić (2005: 125-171). 
2. The schism of 1517 fragmented the image of the world and led to religious pluralism in Europe, as well as an unprecedented spiral of religious violence culminating in the Thirty Years' War. The inability to end military conflicts with a definitive victory of one side over the other showed that a way out of long-lasting and exhausting religious conflicts was not possible in the domain of worldview morality, but that it should rather be sought in a new domain of public or political morality centered on the value of political peace.

3. Modern skepticism, in particular Montaigne's, has shown that every human idea and action can be questioned except for self-preservation, which is the only reliable and universal element in human lives. It was Hugo Grotius who introduced the idea of self-preservation into the moral domain of natural rights and thus set the course for the development of modern political philosophy.

\section{Interpretative Approaches to War and the Genesis of the Value of Political Peace}

Every war is violence, but it is understandable that not all violence, except in the figurative sense, is war. War violence is characterized by planned and extremely destructive large-scale military conflicts between two or more political communities or communities driven by political goals. War violence is usually preceded by intense and systematic symbolic violence and a substantial ideological reduction of an image of the world. This is a necessary condition for the homogenization of one's own ranks and the simultaneous demonization of the opposing side. Without this, it would be hard to imagine the fight to the death between people who, as a rule, do not know each other, have nothing personally against one another, and even follow similar life patterns.

Interpretive approaches to war formulated three ideal-typical positions: political realism, fundamentalist moralism of holy wars, and various natural law theories and their derivatives. The position of political realism justifies and limits war solely by national interests and prudential reasons. To such a view is usually attributed moral skepticism and amoralism, even though it is rather a break with traditional morality and the establishment of a special and distinct public or political morality at the heart of which is the preservation and affirmation of the power of one's own political community. ${ }^{15}$ Political realism in principle does not reject classic moral requirements; it only judges them in the light of the supreme criterion of particular consequentialism - whether such requirements contribute to or undermine

15 The crucial role in constituting the independence of political ethics and its detachment from the limitations of traditional ethics - with which then emerges the problem of "dirty hands" of politics - belongs, of course, to Machiavelli. See Machiavelli (2014), and for interpretations, see Berlin (2013) and Pocock (1975). 
the value of preserving and expanding the power of the political community in question.

The second position - fundamentalist moralism of holy wars - is typical of religiously inspired political radicalisms, but also of their secular ideological imitators. Both positions see in a panaceanly imagined war of all wars - whether it is guaranteed by the transcendent reasons of God's providence or philosophical-historical reasons of historical necessity, whether it is the terrible Last Judgment or World Revolution - the instrument of righteousness and of propagating the true values of salvation and/or emancipation. ${ }^{16}$ Not only do such positions clearly mirror the underlying conceptual paradox of every war - war violence as both a way of ending violence and a means of bringing peace - but they also testify to historical dramas in which the means used - fanatic violence and mass destruction - often vastly exceed merely possible, uncertain, distant and only proclaimed goals. ${ }^{17}$

The third, theoretically most far-reaching position consists of a variety of diverse theories interconnected by a 'family resemblance' of being grounded in some version of natural law theories and its derivatives. Within such a broad position, we can distinguish two main branches. According to the first one, war is inevitable and/ or possible and available moral interventions and restrictions are ultimately reduced only to the domain of limited regulation of methods of warfare. It is possible, and even necessary, to bring order into the disorder of war by means of reasonably permissible moral limits of action, which cannot be transgressed without moral condemnation. The most far-reaching contribution of this group of theories is the distinction between unjustified and justified wars. ${ }^{18}$ It rests on a set of reasonable and restrictive moral requirements concerning reasons for war, the way it is waged, and the post-war establishment of peace. The most prominent representatives of that

${ }^{16}$ For more about the roots of political radicalism in modern religious movements, see Walzer (1969).

17 The famous closing lines of Branko Miljković's poem Everyone will write poetry - "Those who cannot stand the song shall listen to the storm, but: will freedom itself sing as slaves have sung of it?" - poetically reveals the shadow of apprehension accompanying every emancipating violence.

18 The words 'justified' and 'just' are often used synonymously in Croatian philosophical literature, thereby obscuring an important semantic distinction. The term 'just war' is more appropriate for understanding war within the fundamentalist-moralistic perspective insofar as it gives war an unambiguous, direct and unquestionable status of an instrument in achieving the purposes of justice, whereas the term 'justified war' is more appropriate for the third position according to which war is inherently evil, but in certain and strictly defined circumstances it can be justified or excused by more important, overriding reasons in the name of which an even greater and longerlasting evil is being averted. 
long tradition are Christian thinkers - from Aurelius Augustine ${ }^{19}$ and Thomas Aquinas, to 16th-century Portuguese and Spanish Dominicans and Jesuits such as Francisco de Vitoria and Francisco Suarez, to modern neo-Thomist philosophers such as John Finnis (1996) and Joseph Boyle (1996).

The secular version of the theory of justified and unjustified wars was first developed by Hugo Grotius. The political assumptions and implications of his argument, based on the humanist tradition, ${ }^{20}$ aim to identify compelling reasons for international justice and delegitimize certain types of wars, but also justify the Dutch colonial and imperial military campaigns. ${ }^{21}$ The most prominent contemporary proponent of the distinction between justified and unjustified wars is Michael Walzer (1977 and 2004), who, on the one hand, restores the tradition of natural law, but, on the other hand, eliminates any apriorism and openly acknowledges the limits of theoretical coherence in difficult questions of the morality of war. Walzer's most significant contribution is considerably narrowing down within his categorical apparatus the intuitively permissible notion of justified war, which he does with a convincing insistence on the decisive importance of context, concrete necessities and responsibility of individual and collective subjects.

Whereas the first group of theorists within this position distinguishes between justified and unjustified wars on moral grounds, the second group is much more

19 Augustine was the first to make a comprehensive and far-reaching theory of justified war which, in contrast to early Christian pacifism, tentatively accepts the necessity of warfare insofar as it introduces a moral perspective and a dividing line in understanding and explaining wars. The need to distinguish between justified and unjustified wars is explained by Augustine by three related reasons: 1) a physical act and its moral meaning differ, with Christian pacifism referring to questions of motivation or matters of heart and mind. This means that a Christian soldier does not sin when taking an enemy's life if he acts with benevolence and regret in his heart (Barnes, 1997); 2) Augustine's concept of love for God, oneself, and one's neighbor implies a paternalistic concern "that one's neighbor loves God", which means justifying the necessity of coercion, including ultimately even war, but not "because one is proud of authority, but because one loves mercy" (Augustine, 1997, XIX. 14); 3) it would be far worse if the unrighteous ruled over the righteous (ibid., XIX. 15, p. 57).

${ }^{20}$ By the end of the 16th century, two different paradigms were formed on issues of international justice and, consequently, on issues of war and peace: scholastic and humanistic. The scholastic paradigm, relying on medieval theologians and jurists of the postglossator school, such as Baldus de Ubaldis, and exemplified in Luis de Molina's work De iustitia et iure, rejects the justification of preventive war or war waged for glory. On the other hand, the humanistic paradigm, based on the Roman rhetorical and political tradition and initially exemplified in Alberico Gentili's work De iure belli, emphasizes the idea of a natural and universal human community governed by natural law, which then implies the justification and naturalness of subjugating barbarians and infidels. See Tuck (1999).

${ }^{21}$ With that in mind, Richard Tuck (1999) doubts whether the lobby of the Peace Palace in The Hague is really the most appropriate place for a bust of Hugo Grotius. 
radical. It seeks to establish the conditions for the termination of wars and the establishment of a positive and lasting value of political peace. The most prominent representatives of this abolitionist perspective are de Saint-Pierre ${ }^{22}$, Thomas Paine ${ }^{23}$ and Immanuel Kant ${ }^{24}$.

Having distinguished between various layers of meaning and distinctions in the concept of war, we will now examine the elementary distinctions in the concept of peace. The concept of peace in European culture is formulated in three main contexts and meanings. Firstly, there is the all-encompassing and undifferentiated cosmological peace. Ancient philosophers, in a multitude of different statements, opposed the supposed original principle of disorder or chaos with the principle of order or cosmos. The most systematic of them was Plato, who established on three related levels the metaphysical primacy of order, harmony and inaction over disorder, movement or emergence, and disharmony. Just as the demiurge, or the creator of the orderly world in Plato's Timaeus, creates a harmonious world from a multitude of different and mutually incompatible beings, so does the statesman, imitating the cosmic order, create a harmonious polis or political community from a multitude of human whims, habits and desires (Platon, 1997, 2017). In Republic,

22 Abbé de Saint-Pierre's project for perpetual peace, published in 1712, is the first systematic and comprehensive plan for lasting peace in Europe, with the exception of Henry IV's previous plans to achieve European peace by relying primarily on the concept of balance of power. Saint-Pierre eliminates the unreliable concept of balance of power between the French and Austrian ruling houses and seeks institutional guarantees of peace in the form of a political body of united Christian states, which he calls the League of Europe or European Alliance and which, modeled on the "seven sovereignties of the Netherlands or the thirteen sovereignties of Switzerland", would represent a permanent congress or "General Assembly of Europe" in which eighteen Christian states would have a vote (De Saint-Pierre, 1984). De Saint-Pierre's outline for the project of perpetual peace, which is to guarantee security and free trade, oscillates between the (con)federalism of sovereign states and the modified medieval res publica Christiana. See Riley (1975).

${ }^{23}$ Paine envisioned the idea of global peace as an inevitable and self-evident consequence of the global revolution spurred by the American and French revolutions in which he himself took an active part. With the disappearance of monarchies and aristocracies and with the establishment of democratic republics, Paine is convinced that universal peace is guaranteed because "as war is the system of government on the old construction, the animosity which nations reciprocally entertain is nothing more than what the policy of their governments excites to keep up the spirit of the system. Each government accuses the other of perfidy, intrigue, and ambition, as a means of heating the imagination of their respective nations, and incensing them to hostilities. Man is not the enemy of man, but through the medium of a false system of government" (Paine, 1987: 119-120).

${ }^{24}$ Kant not only considered the demand for abolishing wars a dictate of moral-practical reason and deemed the ideal of perpetual peace "the highest practical good" (The Metaphysics of Morals, Doctrine of Right, part II, ch. 3, par. 62), but he was also the first in the modern era to regard humankind as a moral and legal subject, thereby introducing ius cosmopoliticum or the law of world citizenship into public law (Kant, 1967 and 2000). 
having previously indicated the order of the world of ideas (cosmic peace) and the unity of a political community (political peace), Plato introduces the third dimension of peace - harmony, "health, beauty, and good condition of the soul" (444 e) or psychological peace, which is achieved in a virtuous harmony that gives a person's every motivational power its corresponding place - meaning that the mind is the hegemon over will and lust. All these three dimensions of peace - cosmic, political and psychological - are made possible by the same homogeneous idea or form of the Good, which, through the privileged insight of philosophers, becomes relevant and applicable to political and personal life.

\section{The Genesis of the Emancipation of the Idea and Value of Political Peace}

The essential similarity of the three instances of the idea of Good, and consequently the levels of peace, was first questioned by Aristotle with two considerate but also directly critical attitudes. "It has been held by some thinkers that beside the many good things we have mentioned, there exists another Good, that is good in itself, and stands to all those goods as the cause of their being good" (Nicomachean Ethics, $1096 \mathrm{~b}$ ). Aristotle strengthens his defense of the diversity and pluralism of goods within the teleological picture of the world - with a critical thesis about the essence of the city-state: "Yet it is clear that if the process of unification advances beyond a certain point, the city will not be a city at all for a state essentially consists of a multitude of persons, and if its unification is carried beyond a certain point, city will be reduced to family and family to individual" (Politics, 1261 a). After a convincing argument, Aristotle concludes with the following assertion: "Hence it is manifestly possible to be a good citizen without possessing the goodness that constitutes a good man" (ibid., 1276 b). In short, Aristotle connected the plurally understood concept of good to the realm of human praxis and paved the way for independent examination of political harmony or public peace irrespective of cosmic and psychological peace.

In reconstructing the preconditions for the formation and emancipation of the modern value of political peace, it seems indispensable to point out the contributions of three medieval thinkers: Aurelius Augustine, Marsilius of Padua, and William of Ockham. In the new historical, political and theoretical context of the 16th and 17 th centuries, their rudimentary ideas about political peace gained new layers of meaning in the works of Jean Bodin and Hugo Grotius. It was Thomas Hobbes who provided a systematic theoretical justification of political peace based on instrumental rationality and pragmatic choices, whereas Immanuel Kant developed the idea of perpetual world peace from an ethical and legal perspective. Since the scope of this paper is limited to an examination of the early genesis of the idea and value of political peace, we will consider only the medieval contributions of Aurelius Augustine, Marsilius of Padua, and William of Ockham. 


\subsection{Aurelius Augustine: Limited Order of Political Peace in the External Harmony of Human Wills}

Through his theology of the fallen man, Augustine has paradoxically affirmed the value of political peace. His transcendent eschatology has indirectly opened two perspectives: a) methodically negative or passive anthropocentrism - for despite original sin and the human fall from grace, the salvation of mankind (or at least those chosen ones) becomes the meaning of all cosmological and historical events; b) political realism - by consigning ethical perfection to the afterlife, Augustine realistically approaches the examination of the human psyche, morality, sociability and politics (Deane, 1963; Raunić, 2005: 61-88).

The ultimate purpose of man is to achieve the kind of peace that results from the harmony between human loves - for Augustine this is the general term for human passions and desires - and the eternal order of things. True peace, or tranquillitas ordinis, in which all contradictions, conflicts, and oppositions disappear, is possible only in the afterlife, in the blissful contemplative union of the Christian soul with God. Augustine contrasts perfect or heavenly peace with earthly peace, "the peace of Babylon", which "the people call happiness" and which is characterized only by the imperfect and temporary absence of war. Augustine has freed earthly or political peace from high moral purposes - a political community does not exist because of human goodness, but because of human wickedness - and thus, partly even against his intention, realistically and far-reachingly determined the meaning of the notion of political peace. "The earthly city, which does not live by faith", says Augustine, "seeks an earthly peace, and the end it proposes, in the well-ordered concord of civic obedience and rule, is the combination of men's wills to attain the things which are helpful to this life" (De civitate Dei, III, 19.17, p. 61). Earthly peace rests on dominia or coercive institutions - of rulers over subjects, masters over slaves, and owners over property - which, both as punishment and as a cure for sin, bring a certain order into the fragmented order of a sinful condition or selfdestructive anarchy, thus enabling political peace. Such a limited and temporary earthly or political peace, though only a pale reflection of heavenly peace, becomes in a conceptual sense an admittedly inferior, yet independent subject of research. In his theocentric and teleological ontology, Augustine distinguishes several dimensions or degrees of peace. "The peace of the body then consists in the duly proportioned arrangement of its parts. The peace of the irrational soul is the harmonious repose of the appetites, and that of the rational soul the harmony of knowledge and action. The peace of body and soul is the well-ordered and harmonious life and health of the living creature. Peace between man and God is the well-ordered obedience of faith to eternal law. Peace between man and man is well-ordered concord. Domestic peace is the well-ordered concord between those of the family who rule 
and those who obey. Civil peace is a similar concord among the citizens. The peace of the celestial city is the perfectly ordered and harmonious enjoyment of God, and of one another in God. The peace of all things is the tranquility of order. Order is the distribution which allots things equal and unequal, each to its own place" (ibid., 19.13, p. 51). Such a connection between Christian dogmatism and the Neoplatonic hierarchy of dimensions or types of peace allows Augustine to simultaneously place the relationship between heavenly and earthly peace in a tense relationship of discontinuity and continuity. It is characterized by discontinuity insofar as, due to the perfection, wholeness, and eternity of heavenly peace, "this alone can be truly called and esteemed the peace of the reasonable creatures" (ibid., 19.17, p. 63). On the other hand, it is a relationship of continuity insofar as the heavenly city, the city of God or the community of people living according to God's word and only sojourning on earth "calls citizens out of all nations, and gathers together a society of pilgrims of all languages, not scrupling about diversities in the manners, laws, and institutions whereby earthly peace is secured and maintained, but recognizing that, however various these are, they all tend to one and the same end of earthly peace. It therefore is so far from rescinding and abolishing these diversities, that it even preserves and adopts them, so long only as no hindrance to the worship of the one supreme and true God is thus introduced" (ibid.). In other words, even though the city of God strives towards true heavenly peace, it nevertheless, while on its earthly pilgrimage, "avails itself of the peace of earth and desires and maintains a common agreement among men regarding the acquisition of the necessaries of life" (ibid.). The relative value of earthly peace, even if - in Augustine's words - only a respite between battles, is thereby established nonetheless.

\subsection{Marsilius of Padua: The Defense of Peace is the Purpose of Jurisdiction and the Source of the Legitimacy of Political Authority}

Whereas Augustine outlined in a methodically negative way the distinctiveness of earthly or political peace by degrading it and making it merely a deceptive and contrasting image of true heavenly peace, Marsilius of Padua, regarded by many as the most significant and influential late medieval political philosopher, was the first to explain the value of political peace in a methodically positive and systematic way. The radicalism of Marsilius's novelty that led to the emancipation of the value of political peace is manifested on two related levels: conceptual and political. At the conceptual level, earthly peace ceases to be an instrument of transcendent purposes and becomes a self-sufficient value. At the political level, the affirmation of the value of political peace meant challenging the Church's pretensions to political power.

Marsilius's basic starting point is naturalistic - a physician by vocation, he relies on experiential knowledge and induction. On the other hand, he received a hu- 
manistic education at the University of Paris, of which he became rector in 1313, and from the position of Averroist Aristotelianism formulated his radically new political theory. ${ }^{25}$ The initial naturalism and Averroistic Aristotelianism are mediated by the modern idea of man's self-positioning and mastering the conditions of human cohabitation. Correct knowledge, Marsilius argues, empowers action, while ignorance leads to resignation to fate. Marsilius's argumentative strategy follows the logic of medical practice. The first step is to diagnose the condition and determine the causes, as Marsilius himself asserts, of society's diseases, which he finds in unregulated conflicts destroying society that result from the absence of a uniform criterion or framework for social and political action. Overlapping authorities with indistinguishable jurisdictions and modes of operation allow the shenanigans of certain strata of society that disturb the balance and harmony of people's life together. The main cause of social unrest and threat to the political community are the unjustified pretensions of the Roman bishop and his church - as Marsilius most often refers to the pope - to civil and political power. The immediate historical and political context of Marsilius's radical political philosophy is the rejection of Pope John XXII to crown Louis IV of Bavaria and recognize his imperial succession. ${ }^{26}$

25 The extent of novelty of Marsilius's political theory is also evidenced by Pope Clement VI's claim that "we had never read a worse heretic than Marsilius", since as many as 240 articles from his work were declared heretical. Cited from Annabel Brett's "Introduction" in: Marsilius of Padua, 2005: xi.

${ }^{26}$ Rivalries and conflicts between ecclesiastical and imperial authority in the early 14th century began with a fierce conflict between the French King Philip IV the Fair, who, due to the war with England, intended to tax the clergy, and Pope Boniface VIII. The pope convened a church council and on November 18, 1302 issued the bull Unam sanctam in which he repeated the classic arguments - since salvation requires the necessary subjection of every man to the ecclesiastical authority and, consequently, the supremacy of ecclesiastical authority over the secular power, no part of church revenues can be taxed without the explicit consent of the pope. Philip IV convoked an assembly of all the estates of France and, as their representative and holder of executive power, condemned the pope and proclaimed imperial jurisdiction over the clergy. After eighteen months of preparations, Pope Boniface VIII intended to announce the excommunication of Philip IV on September 8, 1303, but on the very night before the announcement, the king's troops led by William Nogaret stormed the papal palace at Anagni demanding that the pope resign, restore the privileges of the Colonna family, and hand over all available money. The pope refused, but the locals managed to free him in the morning. A month later, Pope Boniface VIII died and Philip IV threatened to initiate a posthumous trial against him for heresy, fornication and larceny. The new popes, Benedict XI and Clement V, were forced to make concessions to the imperial government, including the abolition of the Templars (March 22, 1312) and the confiscation of their considerable wealth. The open conflict between imperial and papal power broke out again in the third decade of the 14th century, between Louis IV of Bavaria and Pope John XXII. Louis IV of Bavaria and Frederick III of Austria, due to double elections in the Holy Roman Empire, simultaneously claimed the imperial throne. Both sought the support of Pope John XXII, who wanted to secure the independence of the Italian papal state which was the source of income for the papacy at Avignon. 
Pope John XII used the excuse of the emptied throne to strengthen his demand for plenitudo potestatis - complete or absolute power encompassing both spiritual and secular authority - on the basis of which he not only excommunicated Louis IV of Bavaria, but also contested his right to the imperial throne.

The theoretical context of Marsilius's work is the central medieval philosophical-political debate concerning political priority and rivalry between ecclesiastical and political authority, ecclesia militans and regnum, sacerdotium and imperium. On the ecclesiastical side, this discussion was first doctrinally shaped in the 5th century by Pope Gelasius, Augustine's contemporary, with the doctrine of duo sunttwo swords. Fallen human nature desperately needs restraint and some principle of order as punishment for the original sin, as well as a cure for sin as such. The ecclesiastical sword is sharper because it cares for the soul and eternal salvation even of the ruler himself, and thus has precedence over secular authority. ${ }^{27}$ The problem of double obligation - which claim, ecclesiastical or secular, should be given priority and why? - has led to a series of political crises and conflicts. This prompted Marsilius of Padua to put forth, in a radical reversal of the traditional view, a new theory of the legitimacy and role of political authority. In a kind of pre-Machiavellian turn, Marsilius directly and unreservedly advocates the subjectivity and primacy of political power as a necessary condition for the survival and stability of a political community, thereby paving the way for the first theories of sovereignty. ${ }^{28}$

Marsilius uses traditional tenets for new needs. He accepts Aristotle's view that a political community is self-sufficient and that its purpose is the cultivation

The pope took advantage of the contest for the crown and the emptied throne and appointed Robert of Naples imperial vicar in Italy. In 1322, Louis of Bavaria succeeded in defeating his rival Frederick of Austria and demanded that, as the victorious contender for the imperial throne, he should be recognized and crowned by the pope, which John XXII rejected. Moreover, because of protesting against the pope's interference and exercising ruling authority without the pope's consent, Louis was excommunicated on March 23, 1324, and his subjects were released from the political obligation of obedience. To this Louis responded by convening a general council and issuing the Appeal of Sachsenhausen (May 22, 1324) in which he accused the pope of using faith for personal interests and called him a heretic. With the aid of the Ghibellines, supporters of imperial rule, Louis of Bavaria, accompanied by Marsilius of Padua, came all the way to Rome, where he was crowned with the imperial crown given to him by the representatives of the Roman people. On April 18, 1328, he deposed Pope John XXII and appointed the antipope Nicholas V, but failed to establish a stable order in Italy. See Ullmann (2003).

27 Such an explanation of the primacy of ecclesiastical authority extends all the way to Thomas Aquinas and the doctrine of two lights, the sun and the moon, which with unequal power show us the right path to salvation. In the modern era, the doctrine of the relationship between ecclesiastical and political power takes on a more sophisticated form of political theology.

${ }^{28}$ Marsilius's conceptual turn paves the way for Bodin's doctrine of sovereignty as a political way out of unresolvable religious conflicts. 
of virtues, but immediately adds - in a naturalistic vein - that peace is a necessary precondition for this. ${ }^{29}$ Therefore, political peace is conditio sine qua non and an Archimedean point upon which all derived purposes of the political community are based. Marsilius poses the question of the legitimacy of political authority - who should govern, for what reasons and in what way - from the perspective of political peace as the first condition and virtue of public life. ${ }^{30}$ The negative condition for the stability and peace of a political community consists in exposing those who incite social divisions and threaten peace, which is exactly what Marsilius sees in the pope's illegitimate pretensions to civil and political jurisdiction. This is particularly evident in the acquisition of property, as opposed to the original evangelical poverty, and in the pursuit of coercive jurisdiction, as opposed to the doctrinal role of spiritual teachers and their power of persuasion. Such misuse of ecclesiastical and papal authority, which creates social conflicts and divisions, culminates in the illegitimate papal demand for plenitudo potestatis - complete, absolute power that subjugates secular rulers as well.

The positive conditions of peace, as Marsilius systematically argues in Defensor pacis $^{31}$, presuppose determining two things: the common criteria or standard of socially and politically (im)permissible actions, and the subject or bearer of such a standard. The first thing, a general, equal and binding standard that needs to be knowable and have coercive power, refers to law. Laws, according to Marsilius, are either divine or human. Divine law, in so far as it concerns humankind, is knowable, but has no coercive power in this world - not because God has no coercive power, but because God has given people free will and the possibility of repentance in this world. God's rewards and punishments are confined only to the afterlife and,

${ }^{29}$ For the motto of his central work, Defensor pacis, Marsilius takes the words of Cassiodorus, a 6th-century Roman official: "Every realm must desire tranquility, under which peoples prosper and the profit of the nations is safeguarded." He then strengthens this argument about peace as the central virtue of public life with the theological argument about peace as a sign and message of Christ's birth. See Marsilius of Padua (2005, Discourse I, ch. 1, p. 3).

30 Marsilius begins his Defensor pacis with a plea for peace and by invoking Cassiodorus for whom the peace of the community is a precondition for everything that is good, and then in the concluding chapters systematically rounds off his work and explains its title: "This treatise will be called The Defender of the Peace, because it discusses and explains the particular causes by which civil peace or tranquility is preserved and exists, and also those through which its opposite, strife, arises, is prevented and is removed" (2005, Discourse III, ch. 3, p. 557).

31 Defensor pacis was written in 1324 and initially circulated anonymously in Parisian intellectual circles. When Marsilius was identified as its author in 1326, he fled from Paris and took refuge at the court of Louis IV of Bavaria, whom he helped in the fight against papal pretensions to political power. Towards the end of his life, in 1339, Marsilius wrote Defensor minor, in which he elaborated and explained how to apply the ideas put forth in Defensor pacis. See Marsilius of Padua (1993). 
therefore, the Church's demand for coercive jurisdiction in this world is illegitimate and unjustified. Therefore, in this earthly life, there remains only the authority of human law. But who - and why - is the subject or bearer of the law - that is, the legislator? In answering this question, Marsilius relies on the republican tradition and Averroistic Aristotelianism and brings a far-reaching novelty - the legislator is the universitas civium or the universal body of citizens which represents "an eye resulting from many eyes, i.e. an understanding forged from the understanding of many..." (Marsilius, 2005, I. 2, p. 60). The arguments for these claims are of epistemological as well as moral and political nature. The epistemological argument relies in part on Aristotle who allows the possibility that a united multitude, precisely because it is united, makes more prudent decisions than any person would make for themselves. ${ }^{32}$ The moral and political argument lies in the fact that if everyone participates in law-making, laws will benefit everyone and no one will have valid reasons to protest against them. The primary legislator or the universal body of citizens, Marsilius allows, can be represented by its pars valentior, the prevailing part consisting of noblemen, or monarchical authority.

The significance of Marsilius of Padua for modern political philosophy and the affirmation of the value of political peace is threefold. Firstly, Marsilius starts from the conflicting nature of sociability and, against the prevailing moralistic perspective that admonishes the fallen human nature, builds his political theory on the legal regulation of conflict which then enables the order, stability and peace of a political community. Secondly, Marsilius's political philosophy, by emphasizing the human legislator and the primacy of universitas civium (body of citizens) over universitas fidelium (body of believers), reversed the position of Thomas Aquinas and preMachiavellianly enabled the independence and emancipation of the political realm. Thirdly - and in the context of our topic, most importantly - Marsilius's political philosophy has, in principle, established the value of political peace as the foremost virtue of public morality without which no other value of living together is possible. The primary task of political authority, Marsilius asserts (and also emphasizes with the very title of his work) is to be the defender of peace.

\subsection{William of Ockham: Theological Reasons for Rejecting the Papal Claim} to Plenitudo Potestatis

Whereas Marsilius of Padua refuted the papal claim to absolute power from a secular position, thereby defending civil peace, his contemporary William of Ockham reached almost identical theoretical and political conclusions from the opposite theo-

32 See Aristotle, Politics (1988, $1281 \mathrm{a}-1281 \mathrm{~b})$. One should keep in mind that Aristotle takes a moderate stance on this issue, arguing that "though not free from difficulty, [it] seems to contain an element of truth". 
logical position. Ockham repeatedly points out that the papal claim to plenitudo potestatis - absolute power ${ }^{33}$ that also includes political jurisdiction with coercive power - is contrary to the evangelical spirit and mission of the Christian church. Ockham's theoretical starting point and primary goal is to defend the moral purity and authenticity of Christian teachings. Such an intention, by a confluence of historical and theoretical circumstances, brought him to the center of two great and related polemics that would lead to important philosophical and political conclusions about the nature of and relationship between ecclesiastical and secular authority, as well as a well-ordered and stable political community.

William of Ockham, a Franciscan philosopher and theologian at Oxford University - particularly eminent in the fields of logic and metaphysics, and called Doctor Invincibilis (Unconquerable Teacher) - in the 1320s became involved, at the request and encouragement of Michael of Cesena, the general of the Franciscan order, in the Church's internal dispute over the moral value of poverty. ${ }^{34}$ The opinion of radical Franciscans - the so-called spiritualists - was that poverty exemplified the ideal of humility and penance for sins, as well as the supremacy of spirituality over worldly values. The ideal of poverty as a path of moral perfection meant that the Franciscans used things but did not accept ownership of them. In other words, when it came to things and property, they accepted the moral status of usus or use, but not the moral and legal status of dominium or proprietas. In contrast, Pope John XXII, in a series of proclamations, invoked Roman law and insisted that one could not use material goods justly without having ownership rights over them ${ }^{35}$ - property is immanent and essential to man and, therefore, exists by divine law even in the Garden of Eden. The Franciscans, on the other hand, insisted on the difference between iura poli - rights under moral or natural laws - and iura fori-rights under

33 The term plenitudo potestatis initially meant the delegated power of papal legates fully authorized to act as the pope's representatives. By the late 13th and early 14th centuries, this term had taken on a wider meaning within the papal hierocratic theories and implied a view according to which the pope had the highest authority in both ecclesiastical and secular affairs. For the meaning of the term plentiudo potestatis and the differences in its interpretations, both those at the time and contemporary ones, see McCready (1973).

34 An instructive study on the moral value of poverty is provided by Marina Miladinov in her introduction to the collection of Ockham's writings published as Opera Politica (2001), especially in the first chapter "Extreme Poverty and Papal Heresy". See also Kilcullen (2006).

35 A compromise solution for the moral and legal status of property, aiming to mitigate the radicalism of the Franciscan spiritualists, was proposed as early as 1270 by Bonaventure in his work Apologia pauperum, in which he advocates a relation to material goods that in the moral and legal sense goes beyond the right of immediate and mere use of goods (usus), and yet it is not proprietary because goods belong to others. Pope Nicholas III accepted this conciliatory solution, while his successor Pope John XXII explicitly rejected it in the bull Ad conditorem canonum of 1322. 
human law - and claimed that the institution of property was a human creation established by custom or agreement after the Fall and that, therefore, it fell within the remit of positive human legislation.

From the issue of the moral value of poverty and the status of property, the debate between these irreconcilable views moves onto the theological-political question of heresy. Michael of Cesena and William of Ockham were convinced that the pope was heretically deviating from Christian teaching. However, after the Thomist John Lutterell, chancellor of Oxford University, accused him of heresy and proposed an examination of his 56 suspicious theses, Ockham was summoned before the papal court at Avignon in 1324. Together with the general of his Franciscan order, Michael of Cesena, and other Michaelists, Ockham responded to the summons, but as the debate about heresy progressed, the Franciscans realized how it would end - and probably they as well - so they decided to escape first to Pisa and then to the court of Louis IV of Bavaria. In 1328, Ockham renounced his obedience to the pope, who in turn excommunicated him that same year. Thus began the third and for political philosophy most far-reaching level of debate, which was no longer concerned only with the moral status of poverty and property, or the question of orthodoxy and heresy, but with the nature and purpose of papal authority and its relation to imperial authority.

Delineating the jurisdictions of ecclesiastical and political power on the basis of the correct understanding of the nature of their respective authority becomes for Ockham a crucial theoretical and political task that should enable the elimination of social and political conflicts and guarantee political peace. Ockham's strategy, unlike Marsilius's, is not aimed at establishing primacy between the two authorities, but rather it tries to primarily clarify their different natures, jurisdictions and types of action. Therefore, Ockham elevated political and constitutive questions to the level of epistemological questions. His aim is to preserve and protect the purity of the moral values of the Christian community from the political encroachments of heretical popes. ${ }^{36}$ Ockham in fact defends the spiritual authority of the Christian leader by distinguishing between the Avignon popes and the Holy See, and arguing that the ecclesiastical mission can be accomplished only by refraining from meddling in worldly affairs - he opposes the papal claim to plenitudo potestatis with "a perfect freedom of the law of the Gospel” (Ockham, 2001b, XI, p. 421).

The argumentation for refuting the papal claim to absolute power simultaneously relies on theological reinterpretations and natural law tenets consistent with Ockham's ontological nominalism and theological voluntarism (Gillespie, 2008;

${ }^{36}$ Ockham persisted in his views and after 1328 wrote not only against John XXII, but also against his successors Benedict XII and Clement VI. See Canning (1996). 
Coleman, 1999). Ockham contextually interprets Christ's words to Peter - "Whatever you bind on earth will be bound in heaven" (Matthew 16.19) - which Pope Innocent III emphasized as a key argument in favor of the demand for absolute, secular and spiritual authority. Although these words were uttered generally, it is clear from the context that they refer to the question of sin, repentance and absolution (Ockham, 2001a). Ockham strengthens his interpretation by invoking Christ's words from the Gospel of John - "the kingdom of God is not of this world" - and affirmative testimonies from Augustine's writings. Papal power "in no way regularly extends to temporals and to worldly affairs" (Ockham, 2001b, II, p. 397), just as it does not extend to "anything beyond Christian duties" (III, 399) - it is limited only to "those things which are necessary to the salvation and rule and governance of the faithful, respecting always the possessions, rights and liberties of others..." (VII, 411). This means, Ockham concludes, that papal power is ministerial or 'of service', and not dominative or 'of lordship' (VI, 407 and VII, 411). It rests on persuasion and counsel, not on command and coercion, because otherwise "the evangelical law would become a law of servitude" (XI, 425). The highness of apostolic rule consists in three things: "Firstly, that it is in respect of spirituals... secondly, that it is in respect of free persons, not slaves, because by divine law none is the slave of the pope..." (XIII, 429). The third thing concerns emergencies that cannot be determined in advance and during which the pope may exceptionally do "all those things which are necessary for the rule and government of the faithful, even though ordinarily and regularly certain limits have been set to his power, which he is not regularly permitted to overstep" (XIII, 431). Decisions about such emergencies during which the pope is "permitted to do things which are in no way regularly allowed him" would be made by "the council of the wisest men... if they can be had..." (XIII, 431).

If the pope violates the principles of apostolic rule and illegitimately and unlawfully reaches out for absolute power, the ruler can prosecute him for every crime committed against civil laws. Moreover, in exceptional cases of heretical popes, the ruler may convene a general council to adjudicate religious disputes. If the council makes an erroneous judgment, then, as Ockham points out, moral authority is transferred not only to the ruler, but also to the individual conscience of every single Christian believer.

In Ockham's political theory, conflicts between imperial and papal authority are, in principle, resolved in two ways. On the one hand, Ockham precisely defines and separates the jurisdictions and modes of operation of the two authorities. On the other hand, he resorts to powerful natural law rhetoric or awareness of natural equity consistent with right reason, limiting the scope of ecclesiastical and political authority, which places Ockham among the founders of the long-standing and in- 
fluential tradition of natural law. In both of these ways, Ockham's primary goal - to restore the credibility and supremacy of Christian virtues - implicitly leads to the emancipation of political purposes, that is, the stability of the political community and civil or political peace (Shogimen, 2007).

\section{Towards the Idea of Global Political Peace}

After a conceptual analysis and historical examination of the idea and value of political peace at the turn of the late Middle Ages and the early modern era, we shall conclude this paper by indicating the directions in which the value of political peace developed in the early modern age. On the one hand, there was the systematic articulation of political peace as an expression of a distinct political morality, as opposed to metaphysical (or worldview) peace as an expression of a comprehensive religious or philosophical morality. Such a path of abstraction from comprehensive moralities, which abandoned grounding political institutions in metaphysical truths and essential propositions about human nature, was a much-needed result of the efforts to find a theoretical way out of unresolvable religious and worldview conflicts of the 16 th and 17 th centuries. ${ }^{37}$

Bodin's mature theory of sovereignty is essentially nothing but an effort to construct, following Marsilius's understanding of political authority as the defender of peace, the supreme authority that can effectively guarantee the unity and stability of the political community and curb violent conflicts between groups of citizens of different religious affiliations and worldviews.$^{38}$ Bodin's theory of sovereignty, which still bore the mark of personal rule, was systematically developed by Hobbes in the form of an abstract and impersonal conception of political authority or modern state whose main task is to guarantee political peace. Hobbes achieves this primarily with a rudimentary conceptual distinction between the political and the social, the public and the private, political obligation and civil liberty consisting in the silence of the law, where laws prescribe not what should be done, but what should not be done, or where the boundaries are - albeit set by the sovereign's discretionary decision - at which the threat to political peace begins.

The second direction of development of the idea of political peace concerns the international or global level, because the constitution of peace within individual political communities has often been only a precondition for international conflicts

37 Consistent separation of political morality from comprehensive worldview morality - that is, the use and expansion of the structure of tolerance - is also at the basis of Rawls's later efforts to justify his theory of political justice as fairness. See Rawls (1999 and 2000).

38 See Bodin (2002), and for an interpretation, see Franklin (1973), as well as a very instructive study by Dragutin Lalović (2002), published as the afterword to the Croatian edition of Bodin's work. 
and large-scale war destruction. The pioneering role in the field of international law - and only implicitly and conditionally of political peace as well - belongs to Hugo Grotius, who, like other modern political theorists, is not in the focus of this paper. Suffice it to say that Grotius constructs international law in a methodological parallel between the individual and the state, basing it on natural law that allows for self-defense and following self-interest without directly harming others. The ambiguity of Grotius's position lies in the fact that, on the one hand, he seeks to legally regulate international relations, while on the other hand, by extensively interpreting the right to self-defense, which also includes the elimination of threats and the right to administer punishment, he actually justifies the colonial campaigns of the Dutch East India Company. For this reason, Kant, who was the first to establish an articulated ethical-legal paradigm of world political peace, can sarcastically point out that “... Hugo Grotius, Pufendorf, Vatell and the rest (sorry comforters as they are) are still dutifully quoted in justification of military aggression" (Kant, 2000: 125). By contrast, Kant's novelty, undoubtedly relevant in our time as well, is that the value of political peace, in order for it to be perpetual, is supported by two radical ideas: an ethical proposition about humanity as a moral subject and a legal proposition about cosmopolitan law which treats people as citizens of a universal state of human beings, that is, a world peace federation.

Reflections on the moral tendencies in the history of humankind from a broad observational perspective point to the relevance and topicality of Kant's paradigm, despite criticisms of his occasionally excessive Enlightenment optimism and belief in the inevitability of progress. The historical process of the generalization of will and moral progress takes place, according to Kant, through two related but opposite processes. The first one is the historically prevailing process of indirect constitution of the generality of institutions through antagonisms and armed conflicts - that is, through the "unsocial sociability of men" (ibid.: 22). Based on the premises of his teleological metaphysics of nature, Kant is convinced that painful and tragic experiences of destruction "through discord lead to harmony" (ibid.: 130). The opposite process of direct and reflective learning of humankind, which attests to the degree of its liberation from the state of war, is based precisely on the concept of political peace and international justice. World peace is not a utopian algorithm that abolishes all antagonisms and conflicts, but rather it seeks to minimize them through political justice and to resolve them in a civilized and responsive manner beyond war violence. 


\section{REFERENCES}

Arendt, Hannah. 1969. On Violence. Harcourt Brace Jovanovich. San Diego.

Aristotel. 1988. Nikomahova etika. SNL. Zagreb.

Aristotel. 1988a. Politika. SNL. Zagreb.

Augustin, Aurelije. 1973. Ispovijesti. Kršćanska sadašnjost. Zagreb.

Augustin, Aurelije. 1982-1996. O državi Božjoj. Vol. 1-3. Kršćanska sadašnjost. Zagreb.

Barnes, Jonathan. 1997. The Just War, in: Kretzmann, N. and Kenny, A. (eds.): The Cambridge History of Later Medieval Philosophy. Cambridge U. P. Cambridge: 771784.

Benjamin, Walter. 1971. Uz kritiku sile. Studentski centar Sveučilišta u Zagrebu. Zagreb.

Berlin, Isaiah. 2013. The Originality of Machiavelli, in: Against the Current. Princeton U. P. Princeton: 33-100.

Bodin, Jean. 2002. Šest knjiga o republici (selection). Politička kultura. Zagreb.

Bottici, Chiara. 2007. A Philosophy of Political Myth. Cambridge U. P. Cambridge.

Boyle, Joseph. 1996. Just War Thinking in Catholic Natural Law, in: Nardin, T., The Ethics of War and Peace. Princeton U. P. Princeton: 40-53.

Canning, Joseph. 1996. A History of Medieval Political Thought 300 - 1450. Routledge. London.

Coleman, Janet. 1999. Ockham's Right Reason and the Genesis of the Political as 'Absolutist'. History of Political Thought, (20), 1: 35-64.

De Saint-Pierre. 1984. Projekt vječnog mira. Predgovor. Glavne ideje projekta (ed. Joka, M.). Kulturni radnik, (37), 4: 187-200.

Deane, Herbert. 1963. The Political and Social Ideas of St. Augustin. Columbia U. P. New York.

Erasmus of Rotterdam. 1917 (1521). The Complaint of Peace. The Open Court Publishing Co. Chicago.

Fiala, Andrew (ed.). 2018. The Routledge Handbook of Pacifism and Nonviolence. Routledge. New York.

Fiala, Andrew. 2018a. Transformative pacifism: Critical Theory and Practise. Bloomsbury Academic. London.

Finnis, John. 1996. The Ethics of War and Peace in the Catholic Natural Law Tradition, in: Nardin, Terry (ed.): The Ethics of War and Peace. Princeton U. P. Princeton: 1539.

Franklin, Julian H. 1973. Jean Bodin and the Rise of Absolutist Theory. Cambridge U. P. Cambridge.

Gillespie, Michael Allen. 2008. The Theological Origins of Modernity. The University of Chicago Press. Chicago. 
Hegel, G. W. Friedrich. 1987. Enciklopedija filozofijskih znanosti. V. Masleša. Sarajevo. Hegel, G. W. Friedrich. 1989. Osnovne crte filozofije prava. V. Masleša. Sarajevo.

Hobbes, Thomas (ed. C. B. Macpherson). 1985. Leviathan. Penguin Books. Harmondsworth.

Hobsbawm, Eric and Ranger, Terence (eds.). 2007. The Invention of Tradition. Cambridge U. P. Cambridge.

Kant, Immanuel. 1967. Metafizika ćudoređa. Veselin Masleša. Sarajevo.

Kant, Immanuel. 2000. Pravno-politički spisi (ed. Posavec, Z.). Politička kultura. Zagreb.

Kilcullen, John. 2006. The Political Writings, in: Spade, P. V. (ed.): The Cambridge Companion to Ockham. Cambridge U. P. Cambridge: 302-325.

Lalović, Dragutin. 2002. Plaidoyer za državu u Bodinovoj science politique. Afterword in Bodin, 2002.

Locke, John. 2003. Two Treatises of Government (ed. Laslett, P.). Cambridge U. P. Cambridge.

Löwith, Karl. 1990. Svjetska povijest i događanje spasa. A. Cesarec. Zagreb.

Machiavelli, Niccolò. 2014. Vladar. Nakladni zavod Globus. Zagreb.

Marsiglio of Padua. 1993. Defensor minor and De translatione Imperii (ed. Cary J. Nederman). Cambridge U. P. Cambridge.

Marsilius of Padua. 2005. The Defender of Peace. Cambridge U. P. Cambridge.

Marx, Karl. 1974. Kapital. Vol. 1. Prosveta. Beograd.

Marx, Karl. 1976. Privatno vlasništvo i komunizam, in: Marx/Engels, Rani radovi. Naprijed. Zagreb: 272-287.

McCready, William D. 1973. Papal plenitudo potestatis and the Source of Temporal Authority in Late Medieval Papal Hierocratic Theory. Speculum, (48), 4: 654-674.

Mikecin, Igor. 2013. Heraklit. Matica hrvatska. Zagreb.

Monneyron, F. and Mouchtouris, A. (eds.). 2012. Politički mitovi. Tim Press. Zagreb.

Nardin, Terry (ed.). 1996. The Ethics of War and Peace. Princeton U. P. Princeton.

Neuhouser, Frederick. 2008. Rousseau's Theodicy of Self-Love: Evil, Rationality, and the Drive for Recognition. Oxford U. P. Oxford.

Ockham, Vilim. 2001a. Kratak spis o tiranskoj vladavini, in: Opera politica. Demetra. Zagreb: 55-221.

Ockham, Vilim. 2001b. O carskoj i papinskoj vlasti, in: Opera Politica. Demetra. Zagreb: 287-461.

Paine, Thomas. 1987. Prava čovjeka i drugi spisi. Informator/FPN. Zagreb.

Platon. 1997. Država. Naklada Jurčić. Zagreb.

Platon. 2017. Timej, in: Barbarić, D. (ed.): Skladba svijeta. Matica hrvatska. Zagreb. 
Pocock, J. G. A. 1975. The Machiavellian Moment. Princeton U. P. Princeton.

Puhovski, Žarko. 2003. Rat - nastavak moralnosti drugim sredstvima?, in: Roić, S. and Ivić, N. (eds.): Predrag Matvejević: Književnost, kultura, angažman. Prometej. Zagreb.

Puhovski, Žarko. 2015. (Ne)moralnost mira? Peščanik.net, May 29.

Puhovski, Žarko. 2018. Postmoderni pacifizam. Ideje.hr, February 20.

Raunić, Raul. 2005. Pretpostavke liberalnog razumijevanja čovjeka. Hrvatsko filozofsko društvo. Zagreb.

Raunić, Raul. 2014. Rousseauov politički emancipacijski projekt. Filozofska istraživanja, (34), 1-2: 5-22.

Raunić, Raul. 2018. Revolucije i legitimnost, in: Mikulić / Žitko (eds.): Filozofija revolucija i ideje novih svjetova. Filozofski fakultet. Zagreb: 14-49.

Rawls, John. 1999. Justice as Fairness: Political not Metaphysical, in: Rawls, Collected Papers (ed. S. Freeman). Harvard U. P. Cambridge: 388-414.

Rawls, John. 2000. Politički liberalizam. Kruzak. Zagreb.

Riley, Patrick. 1975. The Abbe de St. Pierre and Voltaire on Perpetual Peace in Europe. World Affairs (137), 3: 186-194.

Schmitt, Carl. 2007. Politički spisi. Politička kultura. Zagreb.

Shogimen, Takashi. 2007. Ockham and Political Discourse in the Late Middle Ages. Cambridge U. P. Cambridge.

Tuck, Richard. 1999. The Rights of War and Peace: Political Thought and the International Order from Grotius to Kant. Oxford U. P. Oxford.

Tudor, Henry. 1972. Political Myth. Macmillan. London.

Ullmann, Walter. 2003. A Short History of the Papacy in the Middle Ages. Routledge. London.

Walzer, Michael. 1969. The Revolutions of the Saints: A Study in the Origins of Radical Politics. Atheneum. New York.

Walzer, Michael. 1977. Just and Unjust War. Perseus. New York.

Walzer, Michael. 2004. Arguing about War. Yale University Press. New Haven.

Žižek, Slavoj. 2008. O nasilju. Naklada Ljevak. Zagreb.

Mailing Address: Raul Raunić, Faculty of Humanities and Social Sciences, University of Zagreb, Ivana Lučića 3, 10000 Zagreb.E-mail: rraunic@m.ffzg.hr 